\title{
Antinutrient and Mineral Contents of Two Leafy Vegetables Processed by Different Drying Methods
}

\author{
Chinaza Dike*, Ngwu Nwachukwu, Olachi Osuagwu, Caryne Ezerioha, Sydney Uzoma \\ Department of Biochemistry, Federal University of Technology, P.M.B. 1526 Owerri, Imo State, Nigeria
}

\begin{abstract}
The effects of sun drying and oven drying on the mineral and antinutrient composition of the leaves of Pterocarpus santalinoides (Nturukpa) and Cnidoscolus chayamansa (Obarayim) were determined. Samples were collected from Ideato South and Owerri North Local Government Areas of Imo State, Nigeria. The samples were subjected to sun drying, oven drying at $70^{\circ} \mathrm{C}$ and oven drying at $100^{\circ} \mathrm{C}$. Standard methods of plant analyses were used and results obtained were subjected to statistical analyses using the Statistical Package for Social Sciences (SPSS). The antinutrient contents (alkaloids, tannins, trypsin inhibitors and cyanogenic glycosides) were significantly $(p<0.05)$ decreased with the exception of Saponins which increased significantly $(p<0.05)$ with increasing temperatures but highest in sun dried samples of both vegetables when compared to the fresh. On the other hand, Mineral contents (Sodium, Potassium, Magnesium, Iron, Calcium and Phosphorus) were significantly increased $(\mathrm{p}<0.05)$ with the exception of Iodine which showed significant $(\mathrm{p}<0.05)$ decrease while drying proceeded. Oven drying the leaves of $P$. santalinodes and $C$. chayamansa may be preferred since it is faster, more hygienic, and better preserves the nutrients.
\end{abstract}

Keywords: antinutrient, mineral, dry, vegetable, Pterocarpus, santalinoides, Cnidoscolus, chayamansa.

DOI: $10.7176 / \mathrm{JBAH} / 11-24-02$

Publication date: December $31^{\text {st }} 2021$

\section{Introduction}

Vegetables are those plants whose parts especially the leaves are eaten as food and may be aromatic, bitter or tasteless (Mensah et al., 2008). Leafy vegetables are important sources of nutrients in diets in most Nigerian homes. They contain in reasonable amounts; minerals, vitamins and other nutrients that are usually found in trace amounts in our daily diets (Mosha and Gaga, 1999). Leafy vegetables have been reported to contribute significantly to human wellbeing and to the daily dietary requirements of calcium $(\mathrm{Ca})$ and iron $(\mathrm{Fe})$ in children between the ages of 2 and 5 years (Faber et al., 2007). They are also known to serve many medicinal functions as they contain some important antinutrients that are used in the treatment of diseases (Ahmed, 2007).

Antinutrients such as alkaloids, flavonoids, phenolic compounds, steroids and other secondary metabolites are constituents of leafy vegetables that are useful as bioactive substances in treatment of diseases (Bishnu et al., 2009). Minerals are mainly required for osmoregulation and to activate enzymes (Aslam et al., 2005). The human body does not synthesize minerals, but obtains minerals from diets (Anjorin, et al., 2010).

Pterocarpus santalinoides (Nturukpa) and Cnidoscolus chayamansa (Obarayim) are essential items in the diets in most parts of the Southeast, Nigeria. $P$. santalinoides is a specie of Pterocarpus in the family papilionoidea and grows to about 9-12 meters tall with a trunk diameter of about 1 meter and pinnates leaves of 10-20cm long (Keay, 1989). C. chayamansa commonly known as Chaya (Obarayim), is an attractive shrub which grows up to 3 to 5 meters tall with broad leaves consisting of 3 or more lobes and fleshy petioles (Breckon, 1979).

Vegetables are perishable products as they have high moisture contents (Idowu, 2008). Therefore, it is important to perform appropriate preservation and storage methods to increase the shelf-life for future consumption (Bukola et al., 2011). An advantage of drying vegetables is that, they can be easily converted into the fresh-like forms by rehydrating them and dried vegetables can be available throughout the year through adequate storage (Patricia et al., 2015).

The aim of this study was to comparatively evaluate the effects of drying methods on the antinutrient and mineral contents of $P$. santalinoides and $C$. chayamansa leafy vegetables from Imo State, Nigeria. 


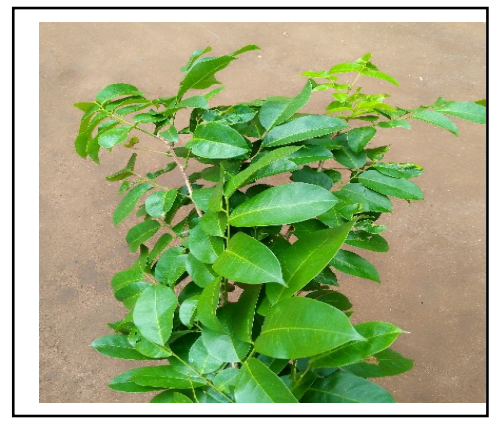

Fig. 1: $P$. santalinoides (Nturukpa) leaves.

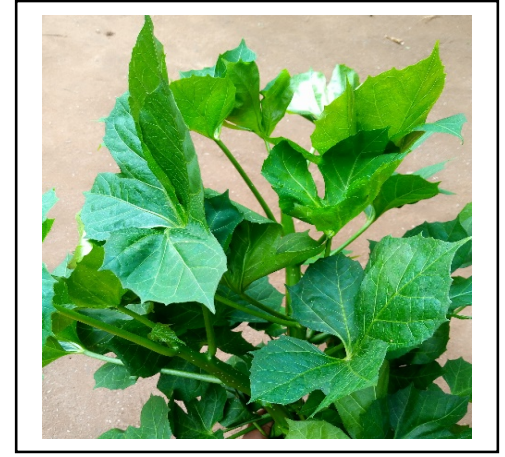

Fig. 2: C. chayamansa (Obarayim) leaves.

\section{Materials and Methods}

\subsection{Sample collection and Processing;}

The $P$. santalinoides and the $C$. chayamansa leafy vegetables were obtained from Ideato South and Owerri North Local Government Areas of Imo State respectively. The vegetables were identified by a Botanist of the department of Forestry and Wildlife Technology, School of Agriculture and Agricultural Technology, Federal University of Technology, Owerri. The leafy vegetables were divided into four (4) equal parts each, according to the conditions of preparation (fresh, sun dried, oven dried at $70^{\circ} \mathrm{C}$ and oven dried at $100^{\circ} \mathrm{C}$ ). Sun dried samples were exposed to sunlight for 5 days. The fresh leaves were washed, blended and stored in a refrigerator prior to analyses. The dried leaves (sun dried, oven dried at $70^{\circ} \mathrm{C}$ and oven dried at $100^{\circ} \mathrm{C}$ ) were ground into powder using a grinding machine. The ground portion was kept in a sterile plastic bottle and stored in a cool and dry place prior to analyses.

\subsection{Determination of Antinutritional Contents;}

The Oxalate and Trypsin inhibitor contents were determined by the permanganate titrimetric and colorimetric methods described by Onwuka (2005). Terpenes and alkaloids were determined using the gravimetric method of extraction and double solvent extraction gravimetric methods respectively (Harborne, 1973). Saponin was determined by the method of vanillin-sulphuric acid colorimetric reaction by Makkar et al. (2007) as modified by Olanrewaju et al. (2017). Phytic acid content was determined by the method described by Davis and Reld and modified by Abulude (2007). The modified alkaline picrate colorimetric method by Balagopalam et al. (1988) was used to determine the cyanogenic glycoside and Folin-Dennis spectrophotometric method (Kirk and Sawyer, 1998) was used in the determination of tannin contents.

\subsection{Determination of Mineral Contents;}

Calcium $(\mathrm{Ca})$, Iron $(\mathrm{Fe})$, Phosphorus $(\mathrm{P})$, Manganese $(\mathrm{Mn})$ and Magnesium $(\mathrm{Mg})$ contents were determined by atomic absorption spectrometric (AAS) method of Adamu et al. (2013). Iodine (I) was determined by thiosulphate titrimetric method described by Kirk and Sawyer (1991). Also, Sodium (Na) and Potassium (K) were determined using the flame photometric method as described by Kirk and Sawyer (1998).

\subsection{Statistical Analyses;}

The results obtained were statistically analysed using one-way Analyses of Variance (ANOVA). The homogenous subset values were measured at $5 \%$ level of significance with the aid of Statistical Package for Social Sciences (SPSS) version 21. 


\section{Results and Discussion}

Table 1: The ANOVA Result of antinutrient contents in fresh and dried P. santalinoides and C. chayamansa Vegetables.

\begin{tabular}{|c|c|c|c|c|c|c|c|c|c|}
\hline \multicolumn{2}{|c|}{ Sample } & $\begin{array}{l}\text { Alkaloids } \\
(\%)\end{array}$ & $\begin{array}{l}\text { Saponins } \\
(\%)\end{array}$ & $\begin{array}{l}\text { Tannins } \\
(\%)\end{array}$ & $\begin{array}{l}\text { Oxalates } \\
(\%)\end{array}$ & $\begin{array}{l}\text { Phytic } \\
\text { acid (\%) }\end{array}$ & $\begin{array}{l}\text { Terpenes } \\
(\%)\end{array}$ & $\begin{array}{l}\text { Trypsin } \\
\text { inhibitor } \\
\text { (Tui/g) }\end{array}$ & $\begin{array}{l}\text { Cyanogenic } \\
\text { glycoside } \\
(\mathrm{mg} / \mathbf{1 0 0 g}) \\
\end{array}$ \\
\hline 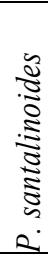 & $\begin{array}{l}\text { Fresh } \\
\text { Sun dried } \\
\text { Oven } \\
\left(70^{\circ} \mathrm{C}\right) \\
\text { Oven } \\
\left(100^{\circ} \mathrm{C}\right)\end{array}$ & $\begin{array}{l}5.10 \pm 0.02^{\mathrm{de}} \\
4.72 \pm 0.02^{\mathrm{bcd}} \\
4.60 \pm 0.04^{\mathrm{bc}} \\
4.39 \pm 0.18^{\mathrm{b}}\end{array}$ & $\begin{array}{l}1.17 \pm 0.01^{\mathrm{b}} \\
5.58 \pm 0.01^{\mathrm{g}} \\
4.39 \pm 0.20^{\mathrm{e}} \\
4.60 \pm 0.10^{\mathrm{f}}\end{array}$ & $\begin{array}{l}2.72 \pm 0.00^{\mathrm{f}} \\
2.11 \pm 0.00^{\mathrm{e}} \\
1.32 \pm 0.00^{\mathrm{d}} \\
0.72 \pm 0.00^{\mathrm{a}}\end{array}$ & $\begin{array}{l}0.16 \pm 0.01^{\mathrm{d}} \\
0.16 \pm 0.01^{\mathrm{d}} \\
0.09 \pm 0.01^{\mathrm{b}} \\
0.07 \pm 0.01^{\mathrm{a}}\end{array}$ & $\begin{array}{l}0.21 \pm 0.01^{\mathrm{c}} \\
0.05 \pm 0.00^{\mathrm{a}} \\
0.03 \pm 0.00^{\mathrm{a}} \\
0.02 \pm 0.00^{\mathrm{a}}\end{array}$ & $\begin{array}{l}0.09 \pm 0.02^{\mathrm{a}} \\
0.11 \pm 0.01^{\mathrm{a}} \\
0.11 \pm 0.01^{\mathrm{a}} \\
0.15 \pm 0.01^{\mathrm{b}}\end{array}$ & $\begin{array}{l}306.67 \pm 23.09^{\mathrm{e}} \\
233.33 \pm 11.55^{\mathrm{d}} \\
206.67 \pm 11.55^{\mathrm{d}} \\
106.67 \pm 23.09^{\mathrm{b}}\end{array}$ & $\begin{array}{l}3.16 \pm 0.02^{\mathrm{d}} \\
3.03 \pm 0.04^{\mathrm{c}} \\
2.84 \pm 0.04^{\mathrm{b}} \\
0.96 \pm 0.02^{\mathrm{a}}\end{array}$ \\
\hline 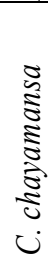 & $\begin{array}{l}\text { Fresh } \\
\text { Sun dried } \\
\text { Oven } \\
\left(70^{\circ} \mathrm{C}\right) \\
\text { Oven } \\
\left(100^{\circ} \mathrm{C}\right)\end{array}$ & $\begin{array}{l}5.20 \pm 0.21^{\mathrm{e}} \\
4.97 \pm 0.58^{\text {cde }} \\
2.80 \pm 0.06^{\mathrm{a}} \\
2.70 \pm 0.04^{\mathrm{a}}\end{array}$ & $\begin{array}{l}0.66 \pm 0.06^{\mathrm{a}} \\
5.81 \pm 0.10^{\mathrm{h}} \\
3.86 \pm 0.01^{\mathrm{d}} \\
3.12 \pm 0.12^{\mathrm{c}}\end{array}$ & $\begin{array}{l}3.84 \pm 0.00^{\mathrm{h}} \\
2.85 \pm 0.01^{\mathrm{g}} \\
1.27 \pm 0.00^{\mathrm{c}} \\
1.26 \pm 0.01^{\mathrm{b}}\end{array}$ & $\begin{array}{l}0.23 \pm 0.01^{\mathrm{e}} \\
0.13 \pm 0.01^{\mathrm{e}} \\
0.06 \pm 0.01^{\mathrm{c}} \\
0.14 \pm 0.06^{\mathrm{a}}\end{array}$ & $\begin{array}{l}0.15 \pm 0.12^{\mathrm{bc}} \\
0.08 \pm 0.00^{\mathrm{ab}} \\
0.04 \pm 0.00^{\mathrm{a}} \\
0.04 \pm 0.00^{\mathrm{a}}\end{array}$ & $\begin{array}{l}0.22 \pm 0.02^{\mathrm{c}} \\
0.23 \pm 0.02^{\mathrm{c}} \\
0.27 \pm 0.01^{\mathrm{d}} \\
0.29 \pm 0.03^{\mathrm{d}}\end{array}$ & $\begin{array}{l}233.33 \pm 11.55^{\mathrm{d}} \\
173.33 \pm 23.09^{\mathrm{c}} \\
106.67 \pm 23.09^{\mathrm{b}} \\
53.33 \pm 11.55^{\mathrm{a}}\end{array}$ & $\begin{array}{l}6.30 \pm 0.02^{\mathrm{h}} \\
5.92 \pm 0.02^{\mathrm{g}} \\
5.65 \pm 0.05^{\mathrm{f}} \\
4.34 \pm 0.04^{\mathrm{e}}\end{array}$ \\
\hline
\end{tabular}

Table 1 shows the antinutrient contents of the fresh and dried vegetables. In the fresh state, there were differences in the levels of antinutrient contents of the two leafy vegetables. Oxalate was found more $(0.23 \% \pm$ $0.01)$ in the fresh $C$. chayamansa leaves than the $P$. santalinoides which contained $0.16 \% \pm 0.01$. Terpenes were also higher $(0.22 \% \pm 0.02)$ in the $C$. chayamansa than in $P$. santalinoides $(0.09 \% \pm 0.02)$, while phytate was higher $(0.21 \% \pm 0.01)$ in $P$. santalinoides than in $C$. chayamansa $(0.15 \% \pm 0.12)$. In the same way, tannins, cyanogenic glycosides (HCN) and alkaloids were higher in C. chayamansa while trypsin inhibitor and saponins were higher in $P$. santalinoides. In the dried form, there were variations in the concentrations of the antinutrients in the vegetables. Sun dried leaves of $P$. santalinoides had reduced alkaloids from $5.10 \%$ to $4.72 \%$ giving a percentage decrease of $7.45 \%$ while the corresponding decrease in sun dried leaves of $C$. chayamansa was from $5.20 \%$ to $4.97 \%$. More of the alkaloids was lost by oven drying at $70^{\circ} \mathrm{C}$ and $100^{\circ} \mathrm{C}$. At $70^{\circ} \mathrm{C}$ drying, the decrease in alkaloids was from $5.10 \%$ to $4.60 \%$ in $P$. santalinoides and from $5.20 \%$ to $2.80 \%$ in $C$. chayamansa. At $100{ }^{\circ} \mathrm{C}$ drying, the alkaloid content decrease in $P$. santalinodes and $C$. chayamansa leaves when compared to the fresh were from $5.1 \%$ to $4.39 \%$ and from $5.20 \%$ to $2.70 \%$ respectively. This result shows that, oven drying led to more reduction in alkaloid contents on one hand. While alkaloid reduction was higher in $C$. chayamansa than in $P$. santalinoides under the same drying conditions. Alkaloids are toxic and can cause health problems if ingested at high concentrations, but they are useful in medicine in that they have strong analgesic properties (Harborne, 1988). Alkaloids are also known to interfere with the regulation of acetylcholine in the body and hence, impairing nerve impulses leading to vomiting, diarrhea and bronchospasm (Cantwell, 1996). Saponins were increased in both leaves following drying under the sun and in the oven. The increase in sun dried leaves was from $1.17 \%$ to $5.58 \%$ in $P$. santalinoides and from $0.66 \%$ to $5.81 \%$ in $C$. chayamansa. This high level increase was attributed to the high reduction in moisture content which amounted to high concentration of the antinutrients in the leaves. But that reduced considerably in the oven dried leaves. At $100^{\circ} \mathrm{C}$ drying, the increase in saponin content relative to the fresh leaves was from $1.17 \%$ to $4.60 \%$ and from $0.66 \%$ to $3.12 \%$ in $P$. santalinoides and $C$. chayamansa respectively. The reduction in the level of saponins increase might be due to heat effect on the antinutrient at the higher temperature. Similar trend was observed in the terpene content of the two vegetables. Tannin was higher in fresh $C$. chayamansa $(3.84 \% \pm 0.00)$ than in fresh $P$. santalinoides $(2.72 \%$ \pm 0.00 ) but reduced to $2.11 \%$ and $2.85 \%$ in sun dried $P$. santalinoides and $C$. chayamansa respectively. When dried in the oven at $70^{\circ} \mathrm{C}$, the reduction was from $2.72 \%$ to $1.32 \%$ in P. santalinoides and from $3.84 \%$ to $1.27 \%$ in $C$. chayamansa. The decrease at $100^{\circ} \mathrm{C}$ drying was from $2.72 \%$ to $0.72 \%$ and from $3.84 \%$ to $1.26 \%$ in both vegetables respectively. This result also shows that, more tannins were reduced by oven drying than sun drying and this is desirable in foods because tannin interferes with protein in diets by coagulating it (Okwu and Ndu, 2006). From the results, the same trend was observed in other antinutrients in the leaves which have antinutrient activities including phytates, oxalate, trypsin inhibitor and cyanogenic glycosides (HCN). Also, there were differences in the antinutrient contents of the vegetables due to the different drying conditions. There were more reductions in the antinutrient contents of the vegetables dried in the oven than the sun dried vegetables. The level of reduction increased with increasing temperatures in the oven. Antinutrients are reduced when foods are dried, which may boost the bioavailability of micronutrients like calcium and magnesium in the body. Heat is known to eliminate natural antinutrients in foodstuffs (Matazu and Haroun, 2004). 
Table 2: The ANOVA Result of Mineral contents in fresh and dried P. santalinoides and C. chayamansa Vegetables.

\begin{tabular}{|c|c|c|c|c|c|c|c|c|c|}
\hline \multicolumn{2}{|c|}{ Sample } & $\begin{array}{l}\text { Sodium } \\
(\mathrm{mg} / 100 \mathrm{~g})\end{array}$ & $\begin{array}{l}\text { Potassium } \\
\text { (mg/100g) }\end{array}$ & $\begin{array}{l}\text { Magnesium } \\
(\mathrm{mg} / 100 \mathrm{~g})\end{array}$ & $\begin{array}{l}\text { Iron } \\
(\mathrm{mg} / 100 \mathrm{~g})\end{array}$ & $\begin{array}{l}\text { Iodine } \\
(\mathrm{mg} / 100 \mathrm{~g})\end{array}$ & $\begin{array}{l}\text { Calcium } \\
\text { (mg/100g) }\end{array}$ & $\begin{array}{l}\text { Phosphorus } \\
\text { (mg/100g) }\end{array}$ & $\begin{array}{l}\text { Manganese } \\
\text { (mg/100g) }\end{array}$ \\
\hline 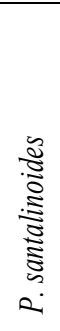 & $\begin{array}{l}\text { Fresh } \\
\text { Sun } \\
\text { dried } \\
\text { Oven } \\
\left(70^{\circ} \mathrm{C}\right) \\
\text { Oven } \\
\left(100^{\circ} \mathrm{C}\right)\end{array}$ & $\begin{array}{l}6.57 \pm 0.06^{\mathrm{a}} \\
11.19 \pm 0.09^{\mathrm{c}} \\
12.45 \pm 0.62^{\mathrm{d}} \\
14.15 \pm 0.49^{\mathrm{e}}\end{array}$ & $\begin{array}{l}87.3 \pm 0.52^{\mathrm{b}} \\
285.67 \pm 2.91^{\mathrm{e}} \\
314.47 \pm 3.00^{\mathrm{f}} \\
341.07 \pm 2.50^{\mathrm{g}}\end{array}$ & $\begin{array}{l}3.51 \pm 0.07^{\mathrm{a}} \\
19.8 \pm 0.28^{\mathrm{c}} \\
27.63 \pm 1.06^{\mathrm{d}} \\
31.95 \pm 0.97^{\mathrm{e}}\end{array}$ & $\begin{array}{l}0.1 \pm 0.02^{\mathrm{a}} \\
0.37 \pm 0.00^{\mathrm{ab}} \\
0.91 \pm 0.04^{\mathrm{bc}} \\
1.47 \pm 0.04^{\mathrm{c}}\end{array}$ & $\begin{array}{l}0.29 \pm 0.02^{\mathrm{e}} \\
0.25 \pm 0.01^{\mathrm{d}} \\
0.14 \pm 0.02^{\mathrm{b}} \\
0.11 \pm 0.01^{\mathrm{ab}}\end{array}$ & $\begin{array}{l}12.67 \pm 0.23^{\mathrm{a}} \\
72.47 \pm 0.41^{\mathrm{c}} \\
80.97 \pm 1.07^{\mathrm{d}} \\
89.0 \pm 2.25^{\mathrm{ef}}\end{array}$ & $\begin{array}{l}89.6 \pm 2.77^{\mathrm{a}} \\
316.6 \pm 1.51^{\mathrm{b}} \\
385.67 \pm 1.44^{\mathrm{e}} \\
421.1 \pm 0.86^{\mathrm{g}}\end{array}$ & $\begin{array}{l}0.01 \pm 0.00^{\mathrm{a}} \\
0.03 \pm 0.00^{\mathrm{b}} \\
0.03 \pm 0.00^{\mathrm{c}} \\
0.04 \pm 0.00^{\mathrm{d}}\end{array}$ \\
\hline 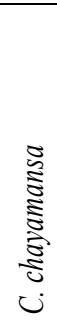 & $\begin{array}{l}\text { Fresh } \\
\text { Sun } \\
\text { dried } \\
\text { Oven } \\
\left(70^{\circ} \mathrm{C}\right) \\
\text { Oven } \\
\left(100^{\circ} \mathrm{C}\right)\end{array}$ & $\begin{array}{l}8.61 \pm 0.30^{\mathrm{b}} \\
23.12 \pm 0.07^{\mathrm{f}} \\
31.69 \pm 0.61^{\mathrm{g}} \\
40.67 \pm 0.28^{\mathrm{h}}\end{array}$ & $\begin{array}{l}67.2 \pm 0.69^{\mathrm{a}} \\
199.07 \pm 3.19^{\mathrm{c}} \\
252.27 \pm 4.73^{\mathrm{d}} \\
285.8 \pm 4.52^{\mathrm{e}}\end{array}$ & $\begin{array}{l}5.06 \pm 0.08^{\mathrm{b}} \\
27.91 \pm 0.03^{\mathrm{d}} \\
35.18 \pm 0.18^{\mathrm{f}} \\
37.11 \pm 1.67^{\mathrm{g}}\end{array}$ & $\begin{array}{l}1.39 \pm 0.03^{\mathrm{c}} \\
5.98 \pm 0.74^{\mathrm{d}} \\
9.61 \pm 0.39^{\mathrm{e}} \\
12.3 \pm 0.28^{\mathrm{f}}\end{array}$ & $\begin{array}{l}0.22 \pm 0.03^{\mathrm{d}} \\
0.18 \pm 0.03^{\mathrm{c}} \\
0.11 \pm 0.01^{\mathrm{ab}} \\
0.09 \pm 0.01^{\mathrm{a}}\end{array}$ & $\begin{array}{l}15.53 \pm 0.42^{\mathrm{a}} \\
67.43 \pm 5.31^{\mathrm{b}} \\
86.0 \pm 2.75^{\mathrm{e}} \\
92.33 \pm 3.46^{\mathrm{f}}\end{array}$ & $\begin{array}{l}92.77 \pm 1.27^{\mathrm{a}} \\
329.47 \pm 2.65^{\mathrm{c}} \\
379.6 \pm 7.48^{\mathrm{d}} \\
395.17 \pm 4.47^{\mathrm{f}}\end{array}$ & $\begin{array}{l}0.01 \pm 0.00^{\mathrm{a}} \\
0.03 \pm 0.00^{\mathrm{c}} \\
0.04 \pm 0.00^{\mathrm{d}} \\
0.04 \pm 0.00^{\mathrm{d}}\end{array}$ \\
\hline
\end{tabular}

○ Values show Mean \pm Standard deviation of triplicate analyses.

$\circ \quad$ Values with same superscript in the same column show no significant difference $(p>0.05)$.

The results of the Mineral content analyses of the fresh and dried vegetables are shown in table 2. The results show variations in the mineral contents of the vegetables prior to drying and under the different drying methods. Sodium content was higher in $C$. chayamansa $(8.61 \mathrm{mg} / 100 \mathrm{~g})$ than in $P$. santalinoides $(6.57 \mathrm{mg} / 100 \mathrm{~g})$ while Potassium was higher in $P$. santalinoides $(87.30 \mathrm{mg} / 100 \mathrm{~g})$ than in $C$. chayamansa $(67.20 \mathrm{mg} / 100 \mathrm{~g})$. Similarly, Magnesium (5.06 mg/100g), Iron (1.39 mg/100g), Calcium (15.53 mg/100g) and Phosphorus (92.77 $\mathrm{mg} / 100 \mathrm{~g}$ ) were higher in $C$. chayamansa than in $P$. santalinoides which had $3.51 \mathrm{mg} / 100 \mathrm{~g}, 0.10 \mathrm{mg} / 100 \mathrm{~g}, 12.67$ $\mathrm{mg} / 100 \mathrm{~g}$ and $89.60 \mathrm{mg} / 100 \mathrm{~g}$ of the same elements respectively. Drying under the sun had significant increases in the mineral contents of the vegetables. Sodium content increased $(6.57-11.19)$ in $P$. santalinoides and $(8.61$ - 23.12) under the same condition in C. chayamansa. In $P$. santalinoides, increases were recorded in Potassium (87.30 - 285.67), Magnesium (3.51 - 19.80), Iron (0.10 - 0.37), Calcium (12.67 - 72.47), Phosphorus (89.6 $316.60)$ and Manganese $(0.01-0.03)$. Similar increases were recorded in the mineral contents of C. chayamansa sun dried leaves including Potassium (67.20 - 199.07), Magnesium (5.06 - 27.91), Iron (1.39 - 5.98), Calcium (15.53 - 67.43), Phosphorus (92.77 - 329.47) and Manganese (0.01 - 0.03). Higher levels of increments were recorded in the mineral contents of the vegetables following oven drying at $70^{\circ} \mathrm{C}$ and oven drying at $100^{\circ} \mathrm{C}$. However, under all the drying conditions, Iodine reduced significantly. The reduction in Iodine content was attributed to the nature of the element which is known to be heat sensitive. Iodine sublimes under normal temperature and pressure and that perhaps explains its ready loss during drying under all three (3) conditions. In general, drying the leafy vegetables reduced the Iodine content significantly but caused significant increases in the mineral content of the leaves. The increase may be attributed to increase in nutrient density in the leaves as a result of moisture loss. However, the greater potassium and reduced sodium ratio has a preventive effect against excessive sodium consumption. The dried samples' high potassium content may provide a therapeutic advantage over fresh samples (Dzomeku et al., 2006). Calcium is a well-known element in the maintenance of strong bone (for the prevention of osteoporosis), muscle contraction and relaxation, as well as blood clotting and vitamin $\mathrm{B}_{12}$ absorption (Otitoju et al., 2014). Iron is a trace element important in many biochemical reactions in the body such as Oxygen binding in haemoglobin and as catalytic centre in most enzymes of Cytochrome systems (Geissler and Powers, 2005). Meanwhile, Magnesium is a mineral which functions in the prevention of bleeding disorders, muscle degeneration and Cardiomyopathy (Chaturvedi et al., 2004). Generally, according to Grosvernor and Smolin (2002), minerals in food are essential for a myriad of metabolic processes.

\section{Conclusion}

The loss of water molecules during drying may account for the observed increases and decreases in antinutrient and mineral components of dried samples of the two leafy vegetables investigated. According to the current findings, the leaves of $P$. santalinoides and $C$. chayamansa contain valuable minerals in both fresh and dried forms, with some antinutrients and iodine being reduced during drying. Because it is faster, more hygienic, and has greater mineral preservation potential, oven drying may be the preferred method of drying and preserving the leaves of $P$. santalinoides and $C$. chayamansa. Therefore, drying generally, may ensure the availability of $P$. 
santalinoides and C. chayamansa vegetables in good form all year round.

Conflict of Interests: Authors have declared that no conflict of interests exists in the work.

\section{References}

Abulude, F.O. (2007). Phytochemical screening and mineral contents of leaves of some Nigerian woody plants. Research J. of Phytochem. 1(1): 33-39.

Adamu, H.M., Ushie, O.A., Gwangwala, A.H., Yadav, R.P., Singh, A., Bhardwaj, A.K., Lone, P.A., Dar, M.M., Parray, J.A. \& Shah, K.W. (2013). Estimation of Total Flavonoids and Tannins in the Stem Bark and Leaves of Anogeisus leiocarpus Plant plant. Int. J. Tradit. Nat. Med. 2, 141-148.

Ahmed, S.S. (2007). Medicinal wild plants from Lahore-Island motorway (M-2), Pakistan, Pak. J. Bot. 39(2): $355-375$

Anjorin, T.S., Ikokoh, P. \& Okolona, S. (2010). Mineral composition of Moringa oleifera leaves, pods and seeds from two regions in Abuja, Nigeria. Int. J. Agric Biol. 12: 431 - 434.

Aslam, M., Anwar, F., Nadeem, R., Rashidi, U., Kazi, T.G. \& Nadeem, M. (2005). Mineral composition of Moringa oleifera leaves and pods from different regions of Punjab, Pakistan. Asian J. Plant Sci. 4: 417 421.

Balagopalam, C.G., Padamaja, S.K.N. \& Morthy, S.N. (1988). Cassava in food, feed and industry, CRC Press, inc. BOCA Raton, Florida, pp 1.

Bishnu, J.U., Sunil, L. \& Anuja, S. (2009). Antibacterial properties of different medicinal plants; Ocimum santum, Cinnamomum zeylanicum, Xanthoxylin arimatum, and Origanum masorana. J. Sci. Engr. Technol. $5: 143-150$

Breckon, G.J. (1979). Studies in Cnidoscolus (Euphorbiaceae). Brittonia 33: 125 - 148.

Bukola, O.B., Tajudeen, M.A.O. \& Taiwo, O.F. (2011). Performance evolution of a solar wind ventilated cabinet dryer. West Indian J. of Eng., Vol.33, pp. 111- 115.

Cantwell, M. (1996). A review of important facts about potato glycoalkaloids. Perishables handling newsletter $87: 26-27$.

Chaturvedi, V.C., Shrivastava, R. \& Upreti, R.K. (2004). Viral infections and trace elements; a complex trace element. Current Science, Vol. 87 pp. $1536-1554$.

Chavasit, V., Pisaphab, R., Sungpuag, P., Jittinandana, S. \& Wasantwisut, E. (2002). Changes in $\beta$-carotene and vitamin A contents of vitamin A-rich foods in Thailand during preservation and storage. J. of Food Sci., Vol. 67 pp. $375-379$.

Dzomeku, B.M., Bam, R.K., Abu-kwarteng, E. \& Ankomah, A.A. (2006). Comparative study on the nutritional values of FHIA - 21 (Tetraploid Hybrid) and apem (Triploid French plantain) in Ghana. J. plant Sci., 1:187 $-191$.

Faber, M., Van Jaarsueld, P. \& Laubscher, R. (2007). The contribution of dark-green leafy vegetables to total micronutrients intake of two to five year old children in rural setting. Water SA 33(3): $407-412$.

Geissler, C.A. \& Powers, H.J. (2005). Human nutrition (1 $1^{\text {th }}$ Edition). Elsevier Churchill Livingstone, Pp25.

Grosvernor, M.B. \& Smolin, L.A. (2002). Nutrition; from science to life. Harcourt college publishers, New York, USA, pp. $288-371$

Harbone, J.B. (1988). Phytochemical methods. Chapman and Hall Ltd, London. Pp 125.

Harborne, J.B. (1973). Phytochemical screening methods. A guide to modern techniques in plant analysis. Chapman and Hall Publication, New York, pp $4-11$.

Idowu, O. (2008). Effects of drying technique on some vegetable leaves. J. of Sci. and Tech., University of Lagos, Nigeria Vol. 2, No. 2 pp. $80-81$.

Keay, R.W. (1989). Trees of Nigeria. Claredon press, Oxford. Pp 493 - 497.

Kirk, R.S. \& Sawyer, R. (1991). Frait pearson chemical analysis of foods. $1^{\text {st }}$ edition. Longman scientific and technical, Edinburgh pp $211-212$.

Kirk, R.S. \& Sawyer, R. (1998). Pearson composition analysis of foods. $9^{\text {th }}$ Edn Churchill living stone, Edinburgh, pp $615-616$.

Makkar, H.P., Siddhuraju, P. \& Becker, K. (2007). Methods in molecular biology: plant secondary metabolites. Totowa: Human Press; p. 93-100.

Matazu, I.K. \& Haroun, A.A. (2004). The effects of drying method on the nutrients and antinutrients composition of the fruit of Hibiscus esculentus (Okra), Nig. J. Renew. Energy, 11:9-13.

Mensah, J.K., Okoli, R.I., Ohaju-obodo, J.O. \& Eifediyi, K. (2008). Phytochemical, nutritional and medical properties of some plants consumed by Edo people of Nigeria. African J. of Biotech. 7:2304 - 2309.

Mosha, C.T. \& Gaga, E.H. (1999). Nutritive value and effect of blanching on trypsin and chymotrypsin inhibitor activities of selected leafy vegetables. Plants Foods Hum. Nutr. 54:271 - 283.

Okwu, D.E. \& Ndu, C.U. (2006). Evaluation of the phytonutrients, minerals and vitamin contents of some varieties of yam (Dioscorea sp). Int. J. of Molecular Med. and Adv. Sci. 2 (2): 199 - 203. 
Olanrewaju, R.A., Ale, E.M. \& Akinwale, S.O. (2017). Qualitative and Quantitative Evaluation of the Phytochemicals in Dry, Wet and Oil Extracts of the Leaf of Morinda lucida. J. of Biol., Agric. and Health 7(7): $22-25$.

Onwuka, G.F. (2005). Food analysis and instrumentation. Theory and practice. Naphithali prints, a division of H.A support Nigeria Ltd, pp2.

Otitoju, G.T., Ene-obong, H.N. \& Otitoju, O. (2014). Macro and micro nutrient composition of some indigenous green leafy vegetables in south-east zone, Nigeria. J. Food process Technol. 5:389.

Patricia, D.O., Lessoy, T.Z., Adom, J.N. \& Sebastien, L.N. (2015). Impact of sun drying on the nutritive and antioxidant properties of five leafy vegetables consumed in Northern Côte d'Ivoire. Asian J. of Applied Sci. $3(3): 628-637$. 